\title{
OPTIMIZATION OF EXTRACELLULAR THERMOPHILIC HIGHLY ALKALINE LIPASE FROM THERMOPHILIC BACILLUS SP ISOLATED FROM HOTSPRING OF ARUNACHAL PRADESH, INDIA
}

\author{
Limpon Bora $^{1 *}$, Minakshi Bora ${ }^{2}$
}

${ }^{1}$ Dept of Molecular Biology \& Biotechnology, Tezpur University, Tezpur-784028; 2Dept of Biotechnology, Dibrugarh University, Dibrugarh - 786004.

\begin{abstract}
Studies on lipase production were carried out with a bacterial strain (Bacillus sp LBN 2) isolated from soil sample of hotspring of Arunachal Pradesh, India. The cells were cultivated in a mineral medium with maximum production at $1 \%$ groundnut oil. The optimum temperature and initial medium $\mathrm{pH}$ for lipase production by the organism were $50^{\circ} \mathrm{C}$ and 9.0 respectively. The molecular mass was found to be $33 \mathrm{KDa}$ by SDS PAGE. The optimal $\mathrm{pH}$ and temperature for activity were 10 and $60^{\circ} \mathrm{C}$ respectively. The enzyme was found to be stable in the $\mathrm{pH}$ range of $8-11$ with $90 \%$ retention of activity at $\mathrm{pH} 11$. The enzyme retained $90 \%$ activity at $60^{\circ} \mathrm{C}$ and $70 \%$ of activity at $70^{\circ} \mathrm{C}$ for $1 \mathrm{~h}$. The lipase was found to be stable in acetone followed by ethanol. The present findings suggested the enzyme to be thermophilic alkaline lipase.
\end{abstract}

Key words: Thermophilic bacteria, Thermostable, Alkaline lipase and Bacillus sp

\section{INTRODUCTION}

Lipases (Triacylglycerol acylhydrolase, EC 3.1.1.3) constitute a group of enzymes defined as carboxyesterases that hydrolyse long chain acylglycerols at the lipid water interface $(7,5)$. The natural function of lipases is to hydrolyze triglycerides into diglycerides, monoglycerides, fatty acids and glycerol. In addition to triacyl glycerol a number of other low and high molecular eight carboxylic-, thiol-, poly-acid esters and amides are also accepted as substrates by these hydrolase enzymes.

Most lipases isolated and reported are found to be mesophilic in nature, which cannot hydrolyze a substrate that exists in solid form at room temperature (4). To overcome this problem a search for thermophilic nature of enzyme is on as thermophilic lipases show higher thermostability, higher activity at elevated temperatures, and often shows more resistance to chemical denaturation. This makes them ideal tools in industrial and chemical processes where relatively high reaction temperatures and organic solvents are used. Thermostable enzymes are usually derived from thermophilic microbial strains, which may be expected to produce intrinsically more heat stable enzymes. The industrial demand for the thermostable enzymes continues to stimulate the search of novel thermophilic microorganisms from various unexploited regions of the earth, as small numbers of bacterial strains producing thermophilic lipases have been reported in the last decade (13). 
Optimization of fermentation conditions for microbial lipase is of great interest, since culture conditions influence the properties of the enzyme produced as well as ratio of extra cellular and intracellular lipases (37). Therefore, optimization of the lipase production has been focused on improving fermentation conditions such as carbon or nitrogen source, temperature, $\mathrm{pH}$, aeration, using inducers and source of inoculum etc $(31,33,11,4,17)$. The induction in lipase production in microorganisms is a process that results in change in the phenotype, which allows the production of energy, required for its metabolism and microbial growth. Edible oils such as vegetable oils, canola oil, and olive oil are used mainly as inducers.

Because of huge variation in application and emerging need of lipases with specific characterstics has prompted to search for new lipases from newer areas with different characterstics. In the present study, we report the findings of thermophilic alkaline lipases produced by thermophilic Bacillus sp isolated from hotsprings of Arunachal Pradesh, India. These findings will provide a meaningful addition to the database on bacterial lipase research in the screening and identification of lipolytic bacteria. The Bacillus strain was sent to IMTECH Chandigarh for identification and will be deposited in MTCC after identification

\section{MATERIALS AND METHODS}

\section{Microorganism, media, and growth conditions}

Bacillus sp was isolated from hot spring of Dirang district of Arunachal Pradesh, India. All analytical chemicals and media components used were of highest purity grade available commercially. A shaking water bath with temperature controller was used. All optical measurements were performed on UV visible spectrophotometer using matched cells of path length $1 \mathrm{~cm}$.

The Bacillus sp isolated were maintained on Nutrient agar slants. The mineral medium was composed as (w/v) $\mathrm{MgSO}_{4} .7 \mathrm{H}_{2} \mathrm{O} 0.04 \%, \mathrm{KH}_{2} \mathrm{PO}_{4} 0.3 \%, \mathrm{Na}_{2} \mathrm{CO}_{3} 0.1 \%$ and $\mathrm{NaCl}$
$0.01 \%$. The $\mathrm{pH}$ of the medium was adjusted to 10.0 .

\section{Experimental procedures}

Lipase production: The mineral medium $(50 \mathrm{ml}$ in $250 \mathrm{ml}$ Erlenmeyer flasks) was prepared and the olive oil was added after emulsification for 15 minutes as sole carbon source. The sodium carbonate was sterilized separately and added to the rest of the medium to adjust the $\mathrm{pH}$ upto 10.0. The medium was inoculated with $10^{4}$ cellsmL $\mathrm{s}^{-1}$ of an overnight culture and incubated at $50^{\circ} \mathrm{C}$ on shaking incubator at $200 \mathrm{rpm}$ for $48 \mathrm{~h}$. The cultures so obtained were centrifuged at $10,000 \mathrm{~g}$ for $15 \mathrm{~min}$. The cell free supernatant thus obtained was used as source of enzyme. The samples were taken and assayed for lipase activity at regular intervals. The measurement of enzyme activity was done in triplicates.

\section{Lipolytic activity}

Enzyme activity was assayed spectrophotometrically (Beckman model DU 530, UV-visible spectrophotometer, Beckman instruments Inc., Fullerton, CA, USA) using $p$ nitrophenyllaurate ( $p$-NPL) (Sigma, St Louis, MO, USA) as substrate. The reaction mixture consisted of $0.8 \mathrm{~mL}$ of $0.05 \mathrm{~mol}$ L-1 phosphate buffer ( $\mathrm{pH} 8.0$ ), $0.1 \mathrm{~mL}$ of enzyme and $0.01 \mathrm{~mol}$ L-1 $p$-NPL. The mixture was incubated at $50^{\circ} \mathrm{C}$ for $15 \mathrm{~min}$, after which $0.25 \mathrm{~mL}$ of $0.1 \mathrm{~mol} \mathrm{~L}-1 \mathrm{Na}_{2} \mathrm{CO}_{3}$ was added and the release of $p$-nitrophenol was measured at $410 \mathrm{~nm}$. One unit of enzyme corresponds to the release of $1 \mathrm{mmol}$ of $p$-nitrophenol liberated per minute under standard assay conditions. The lipase activity was done in initial rate conditions and the activity was measured over time (35).

\section{Determination of protein}

Protein content was measured following the method of Lowry et al. (1951) using Bovine Serum Albumin as standard (24).

\section{Time course of lipase production}

Time course of the lipase production was studied with the medium in shake flasks, for 70 h. $5 \mathrm{mgmL}^{-1}$ inoculum was 
added to $50 \mathrm{ml}$ medium, in $500 \mathrm{ml}$ Erlenmeyer flask and incubated at $220 \mathrm{rpm}$ on a rotary shaker, at $50{ }^{\circ} \mathrm{C}$, for $70 \mathrm{~h}$. Samples were removed periodically and growth as well as lipase activity in the culture supernatant was determined. The growth was measured in terms of OD at $620 \mathrm{~nm}$. Productivity was defined as lipolytic activity units per gram of dry biomass.

\section{Optimization of culture conditions for production of lipase}

The effect of carbon source on the production of lipase, different carbon sources including glucose, galactose, maltose, fructose, trehalose, mannose and sucrose at $1 \%(\mathrm{w} / \mathrm{v})$ concentration were added to the medium. Various nitrogen sources including malt extract, peptone, ammonium sulphate, yeast extract, beef extract, meat extract, and casein at $1 \%(\mathrm{w} / \mathrm{v})$ was supplemented to the production medium. These data were obtained using $100 \mathrm{~mL}$ of the basal medium at an initial $\mathrm{pH}$ of 10.0 at $50^{\circ} \mathrm{C}$ for $48 \mathrm{~h}$. The effect of initial $\mathrm{pH}$ on lipase production was studied using shake flask culture at different initial value of $\mathrm{pH}$. The $\mathrm{pH}$ was adjusted to the desired value using $6 \mathrm{~N} \mathrm{NaoH}$ or $6 \mathrm{~N} \mathrm{HCl}$. The effect of temperature on lipase production was studied by incubating the organism at different temperature $\left(30-80^{\circ} \mathrm{C}\right)$. The effect of $\mathrm{NaCl}$ concentration on the enzyme activity was determined at different salt concentration of $0,5,10$ and $15 \% \mathrm{NaCl}(\mathrm{w} / \mathrm{v})$ at $\mathrm{pH}$ and temperature optimum.

\section{Purification of lipase}

The bacterial isolate was grown for $48 \mathrm{~h}$ at $50^{\circ} \mathrm{C}$ under submerged fermentation. The enzyme of cell free supernatant was precipitated by ammonium sulphate at $60 \%$ saturation at $4^{0} \mathrm{C}$. The precipitate was collected by centrifugation at $10,000 \mathrm{~g}$ for $15 \mathrm{~min}$ at $4^{\circ} \mathrm{C}$ and dissolved in $1 \mathrm{M}$ tris buffer of $\mathrm{pH} \mathrm{7.0.}$ The ammonium sulphate which was associated with precipitate, was removed by dialysis against distill water with nitrocellulose dialyzing bag. The dialysed protein was purified using Sephadex G-100 column ( $2 \mathrm{~cm}$ dia $\times 150 \mathrm{~cm}$ length) gel filtration chromatography. The elution was allowed to proceed at $1 \mathrm{ml} / \mathrm{min}$ of flow rate. The column was run and the fractions were collected in $3 \mathrm{ml}$ volume. UV monitor at $280 \mathrm{~nm}$ measures the absorbance of the fractions. The quantitative activity of lipase was determined as previously described.

\section{Effect of pH on activity and stability}

The $\mathrm{pH}$ effect on activity and stability profiles were studied in a pH range of 3.0- 12.0 using different buffers at $50 \mathrm{mM}$ concentration. For stability $1 \mathrm{ml}$ of enzyme $(5 \mathrm{mg} / \mathrm{ml})$ was mixed with respective buffer and incubated from 0.5 to 24 hours at $50^{\circ} \mathrm{C}$ and then estimating the residual activity.

\section{Effect of temperature on activity and stability}

Temperature effect on lipase activity was determined by carrying out the enzyme reaction at different temperatures in the range of $10-80^{\circ} \mathrm{C}$ at $\mathrm{pH} 10.0$. The thermo stability of the lipase was determined by preincubating the enzyme $(5 \mathrm{mg} / \mathrm{ml})$ at different temperatures ranging form $30-80^{\circ} \mathrm{C}$ for $1 \mathrm{~h}$. After treatment the residual enzyme activities were determined.

\section{Effect of surfactants and commercial detergents on enzyme stability}

Effect of surfactants (Tween 20, Tween 40, Tween 80, Triton X-100, sodium cholate and Sodium dodecyl sulphate (SDS)) and commercial detergents (Ariel, Surf, Rin, Wheel, Tide, and Fena) on enzyme stability was determined under standard assay conditions. $50 \mu 1$ of the enzyme sample were incubated in $50 \mu \mathrm{l}$ of surfactants and detergents (Solution 0.2, 1.0 and $10 \% \mathrm{w} / \mathrm{v}$ at $\mathrm{pH} 8.0$ ) for 1 hour in $50^{\circ} \mathrm{C}$ at $\mathrm{pH} 10.0$ and the residual activity was determined at $\mathrm{pH} 10.0$ for 10 Minutes.

\section{Substrate specificity of the enzyme}

The substrate specificity of the enzyme was studied by titrimetry. The reaction was done in $20 \mathrm{ml}$ Erlenmeyer flask. The substrates used were, castor oil, coconut oil, cottonseed oil, groundnut oil, olive oil, sunflower oil, Span 20, triacetin and tributyrin. The reaction mixture was composed of $1 \mathrm{~g}$ of the above substrate, $23.9 \mathrm{ml}$ glycine- $\mathrm{NaOH}$ buffer $(0.1 \mathrm{M}, \mathrm{pH}$ 9.0) and $0.1 \mathrm{ml}$ enzyme. The mixture was incubated at 
$40{ }^{\circ} \mathrm{C}$ on rotary shaker at $200 \mathrm{rpm}$ for $1 \mathrm{~h}$. The reaction was terminated by addition of $50 \mathrm{ml}$ of acetone-ethanol mixture (1:1). The fatty acids liberated were estimated by titration with $0.05 \mathrm{M} \mathrm{NaOH}$. One unit of enzyme was defined as the amount of enzyme, which liberated one $\mu$ mol of fatty acid, per minute. The end point of the enzyme reaction was 11.0 and the enzyme activity was analyzed at initial reactions.

\section{Effect of organic solvents on lipase activity}

To study the effect of organic solvents on lipase activity was analysed by incubation of enzyme for $1 \mathrm{~h}$ at $40^{\circ} \mathrm{C}$ in $50 \mathrm{mM}$ Tris-Cl buffer (pH 7.0) containing 30\%v/v organic solvents. The control was estimated without organic solvents. The activity was measured at the beginning and the end of the incubation.

\section{RESULTS AND DISCUSSION}

\section{Time course of lipase production}

The production of lipase by Bacillus sp was correlated with growth curve/ biomass. The biomass increased up to 56 hours, after that there was a decline in its amount. Extracellular lipase production exhibited a similar increase with biomass and remains in higher amount in medium upto $72 \mathrm{~h}$ with the production at stationary phase (Fig. 1). The lipase activity appeared to couple with growth .The enzyme production was found to be maximum when the cell population entered into the stationary phase suggesting that enzyme secretion is growth associated. The lipase activity was observed to start soon after beginning of incubation, and the crude enzyme extract obtained after $48 \mathrm{~h}$ of growth in the culture medium exhibited highest activity at the beginning of the stationary phase. A decrease in lipase activity was apparent during the late stationary phase presumably due to the presence of proteases in the culture medium. These results are in agreement with earlier results (32, 14) where maximum lipase activities were observed at the onset of the stationary phase of bacterial growth.

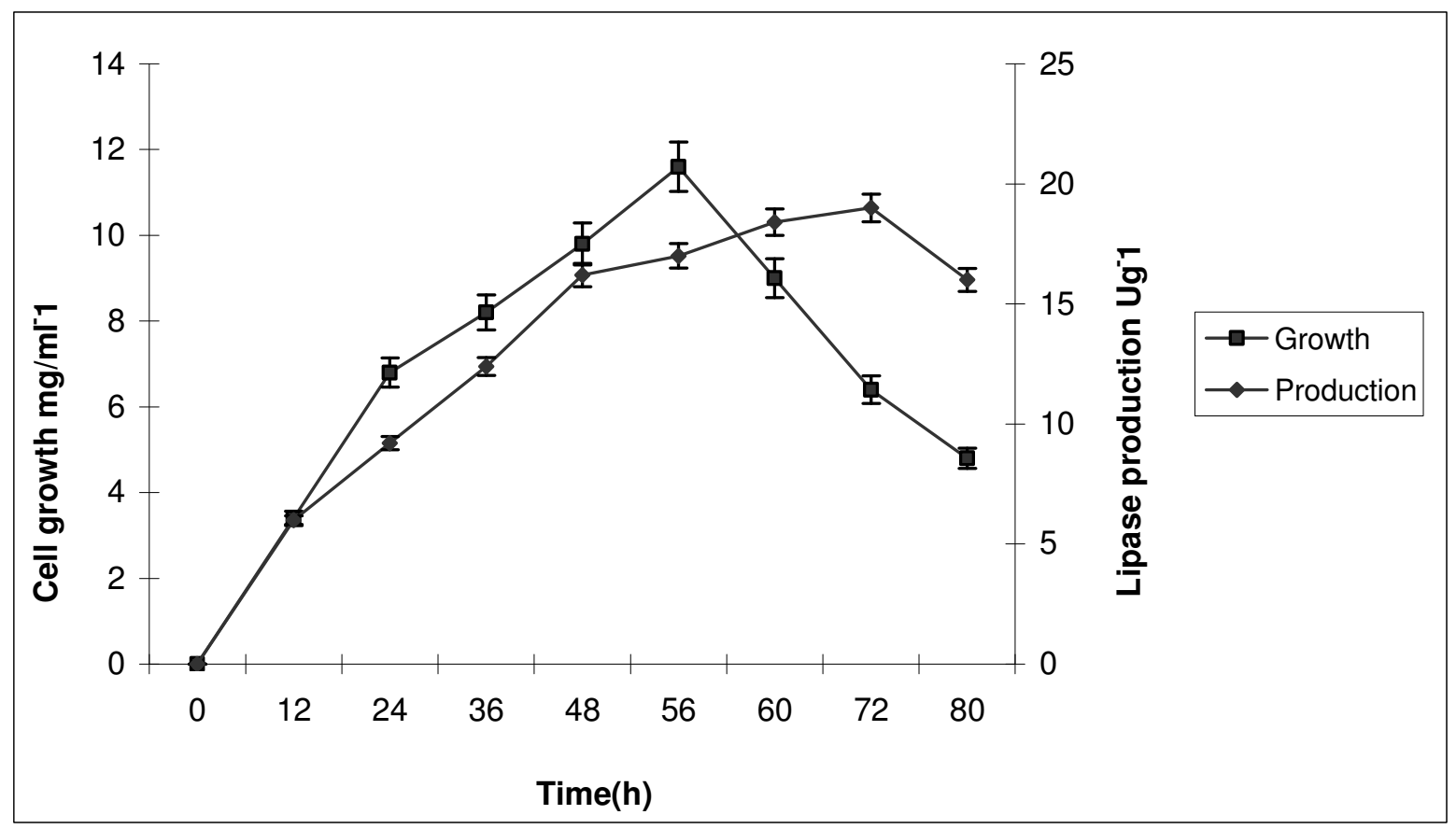

Figure 1. Time course of lipase production. The values are mean \pm SD of three replicates. 


\section{Effect of carbon source on lipase production}

The lipase production was studied with different categories of carbon substrates such lipids, complex nutrient media and readily assimilated substrates. Among these carbon substrates the maximum lipase production was observed in groundnut oil, but it has been found that Bacillus sp could able to utilize a number of other vegetable oils as well as other carbon sources. The maximum lipase production of $18 \mathrm{U} / \mathrm{ml}$ was observed in groundnut oil (Fig. 2). Among the sugars, sucrose and maltose were found to be good substrates for lipase production. The major factor for the expression of lipase activity has always been the carbon source, since lipases are by and large inducible enzymes (23). The enzyme production level markedly increased in the presence of lipid carbon substrates and represents the key mechanism for making a fatty acid carbon source available to the cell during growth on such compounds. The enzyme is probably induced by these substrates $(1,15)$ as fatty acid esters are efficient effectors leading to a significant increase in the enzyme level relative to that obtained with nonlipid substrates such as glucose.

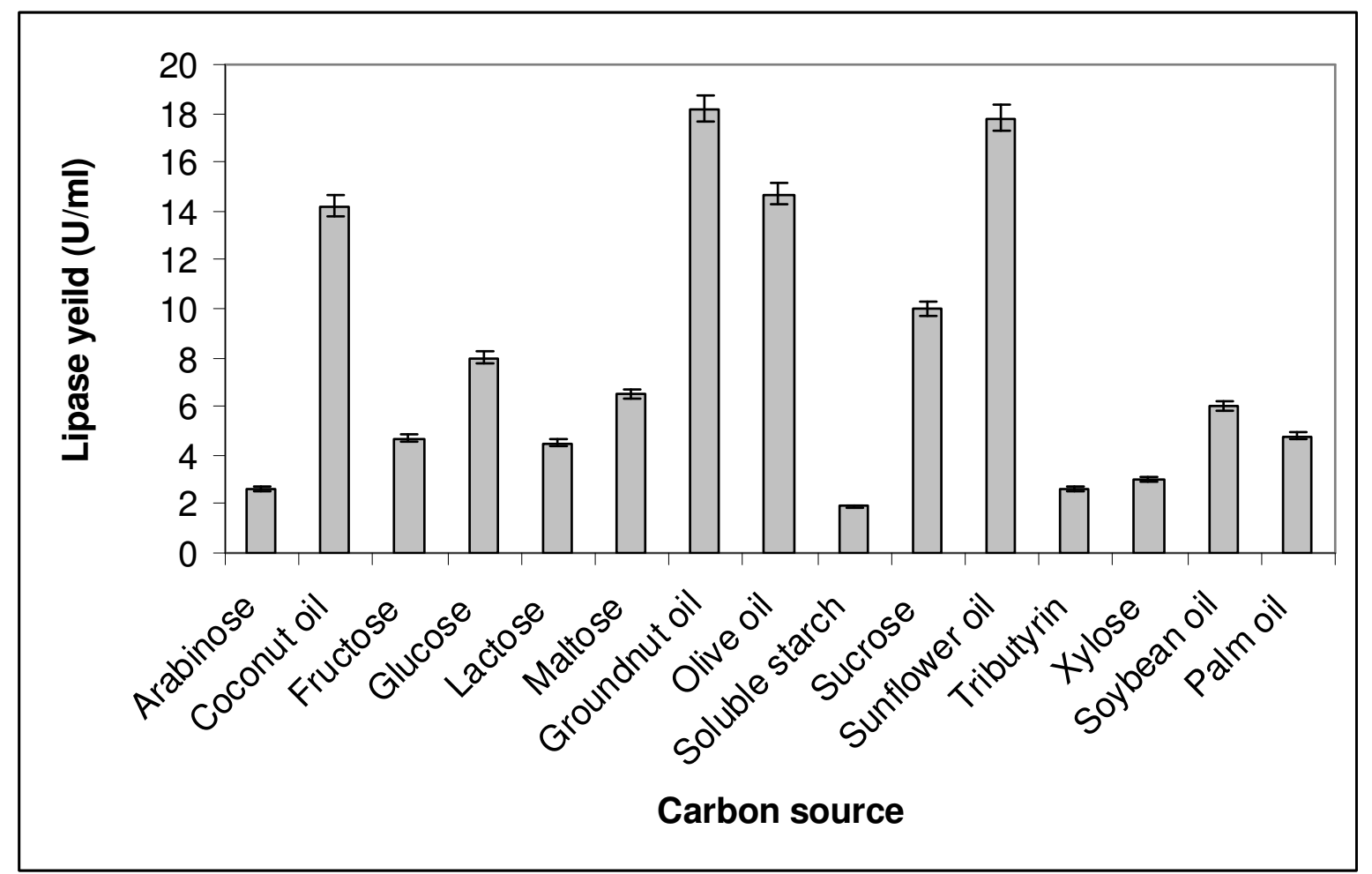

Figure 2. Each value represents the mean of \pm standard errors values with no common letter in column are significantly different at $\mathrm{p}<0.05$.

\section{Effect of nitrogen source on lipase production}

The Bacillus sp grew well in all the nitrogen sources used in this study. Among the different nitrogen sources tested, peptone was found to be the best among all the nitrogen sources tested with a production of $20 \mathrm{U} / \mathrm{ml}$ (Fig. 3). The reason to this effect is the release of $\mathrm{NH}_{4}^{+}$ions from peptone which stimulates the growth and at the same time increase the enzyme yield because of its protease inhibiting nature at low concentration. The results obtained are in agreement with that reported by Gulati et al. (2005) where peptone was found to be 
the best nitrogenous source for lipase production. Similar findings were also reported in other Bacillus sp (8, 21, 34, 38

12). The lipase production was found to be low with soybean meal and corn steep liquor, whereas in other organic and inorganic nitrogen sources the lipase production was in the range of $10-17 \mathrm{U} / \mathrm{ml}$.

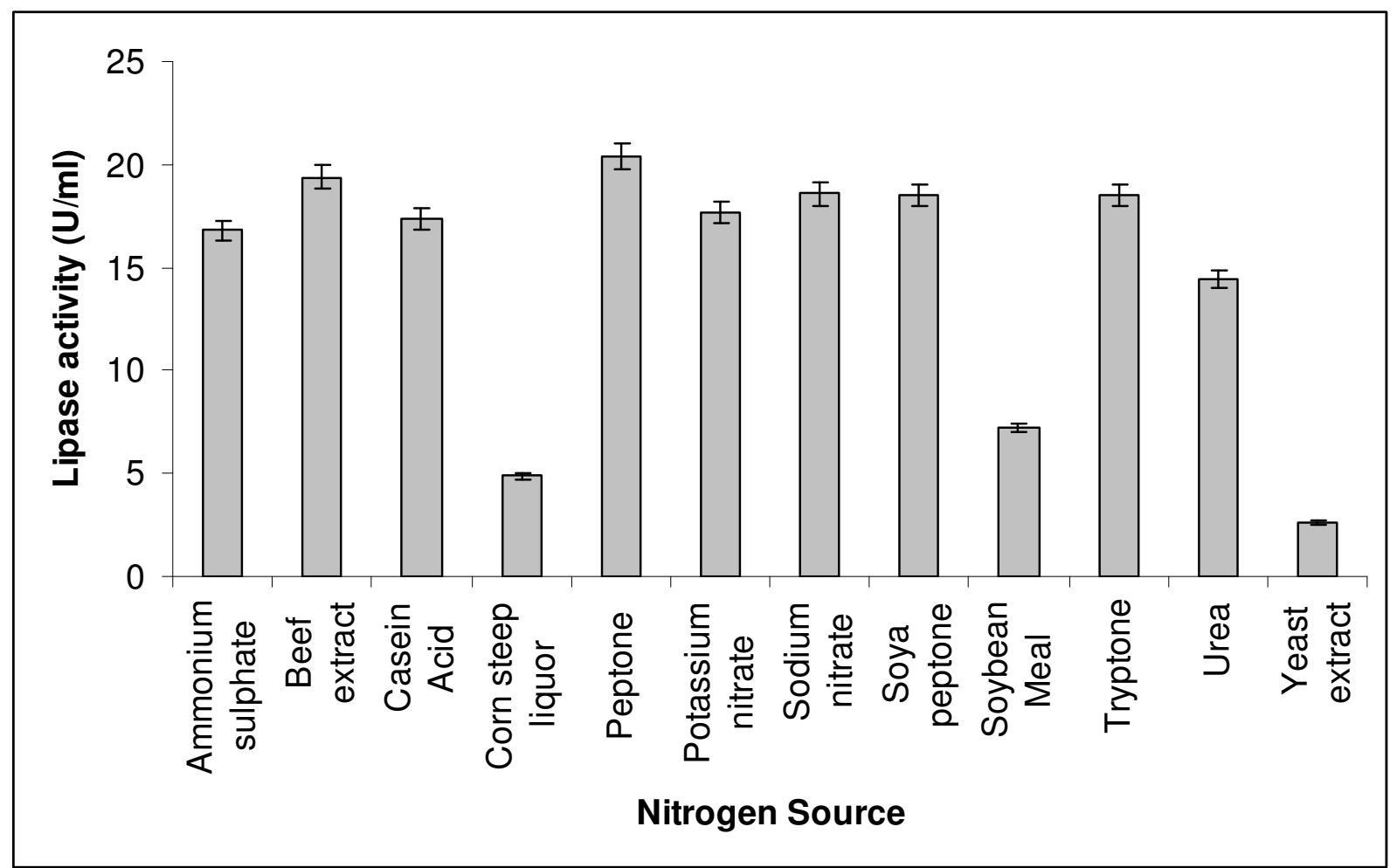

Figure 3. Each value represents the mean of \pm standard errors values with no common letter in column are significantly different at $\mathrm{p}<0.05$.

\section{Effect of temperature and pH on lipase production}

The influence of temperature on lipase production was studied in the range of $30-80^{\circ} \mathrm{C}$ while keeping all the other conditions constant. The optimum temperature for lipase production lipase was found to be $50^{\circ} \mathrm{C}$ (Fig. 5). The temperature regulates the enzyme synthesis at mRNA transcription level and probably translation levels of proteins, thus increases the stability of the proteins and also the production. However the other possible reason for production at elevated temperature may be temperature influences their secretion; possibly by changing the physical properties of the cell membrane (26). The production trend of Bacillus sp
LBN2 was found to be at alkaline range $\mathrm{pH}$ of 8.0 to 10.0 . The maximum production obtained when the initial $\mathrm{pH}$ of the medium was 9.0 (Fig. 4). Medium pH is very important in nutrients absorption and growth of bacteria, stimulation of enzyme production via signaling pathways and release of extra cellular enzymes based on proteolytic mechanism of signal peptidases (27).

The optimum temperature for lipase production corresponds with the growth temperature for lipase production (11). Our results are considerably higher with most of the findings reported earlier (30). 


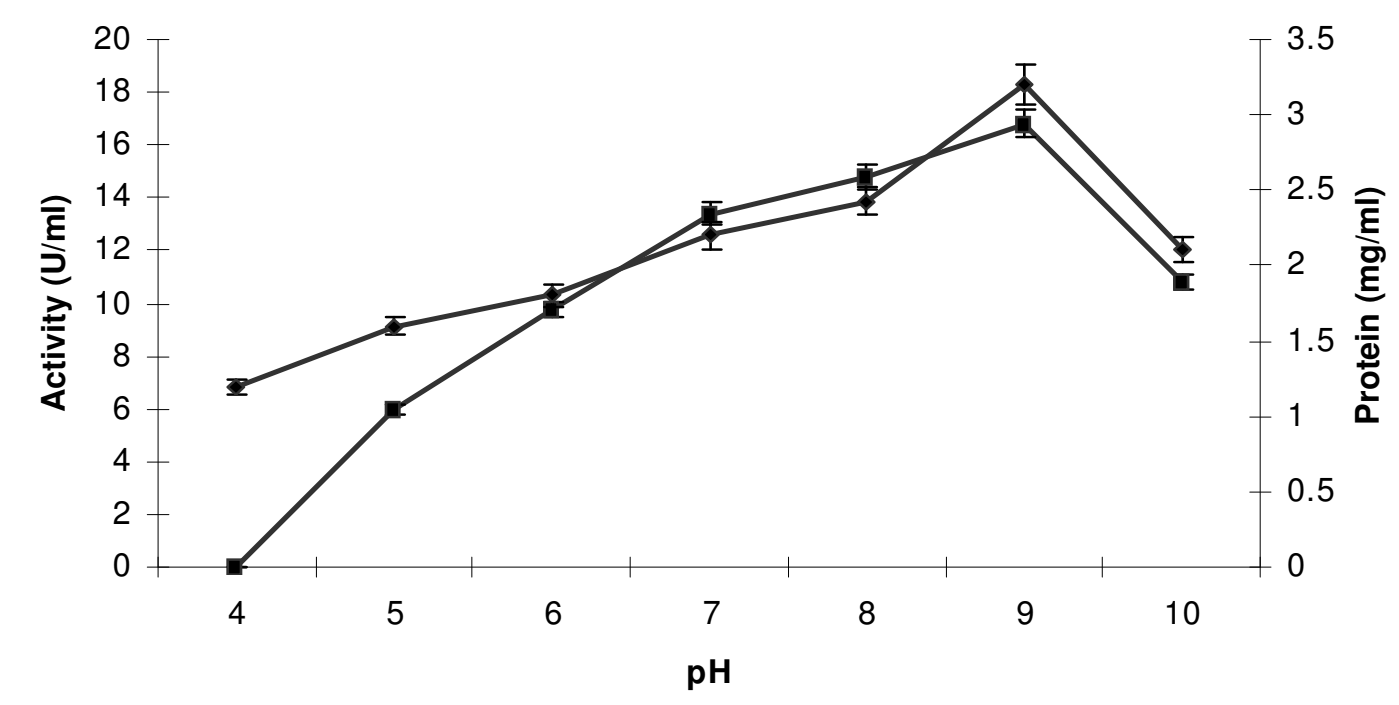

Figure 5. The Effect of $\mathrm{pH}$ on lipase production. The values are mean $\pm \mathrm{SD}$ of three replicates.

--------- Protein (mg/ml) ------ ------ (Activity (U/ml)

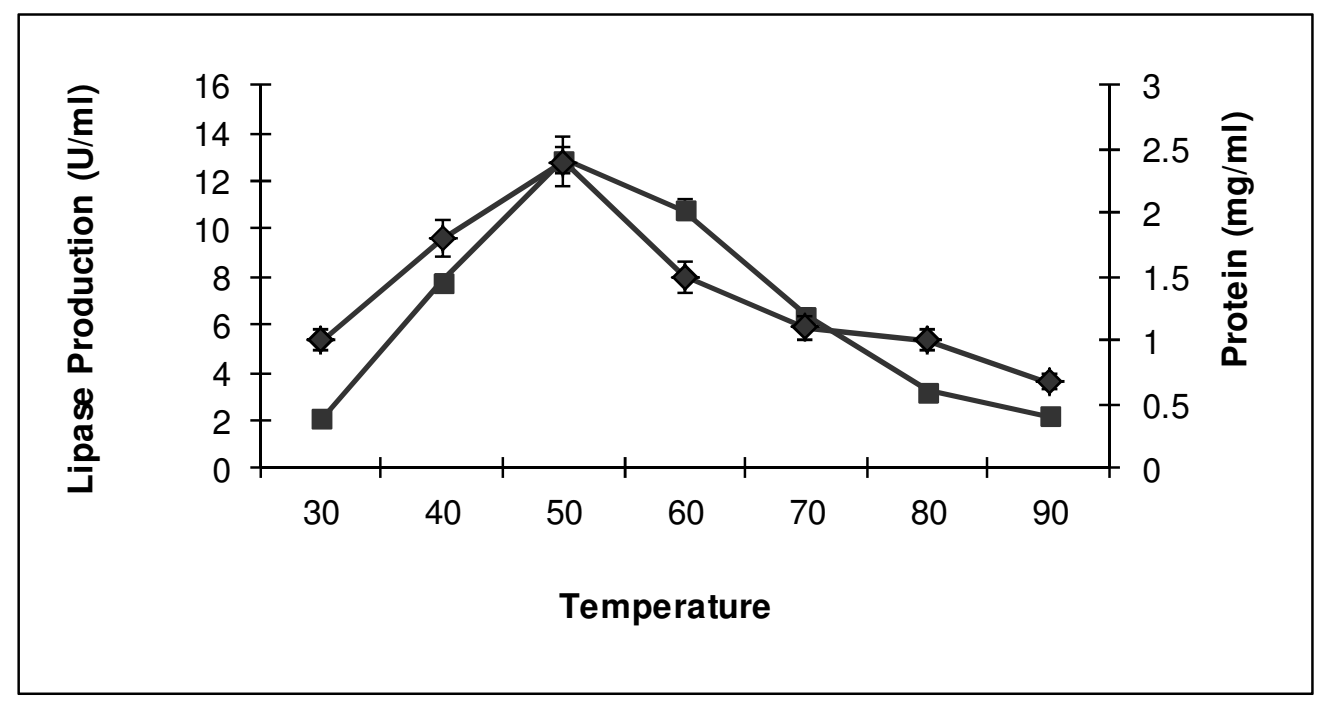

Figure 4. The effect of temperature on lipase production. The values are mean \pm SD of three replicates.

\section{Effect of Salt concentration on Lipase production}

The lipolytic enzyme presents a wide range of tolerance to $\mathrm{NaCl}$ with activation at concentration between 5 and $10 \%$ suggesting the enzyme might be an salt dependent enzyme and salt plays an essential role in either in its activity or stability (Fig. 6). The enzyme production at high salt concentration suggest that the Bacillus $\mathrm{Sp}$ from which the enzyme was isolated is a halotolerant bacteria. 


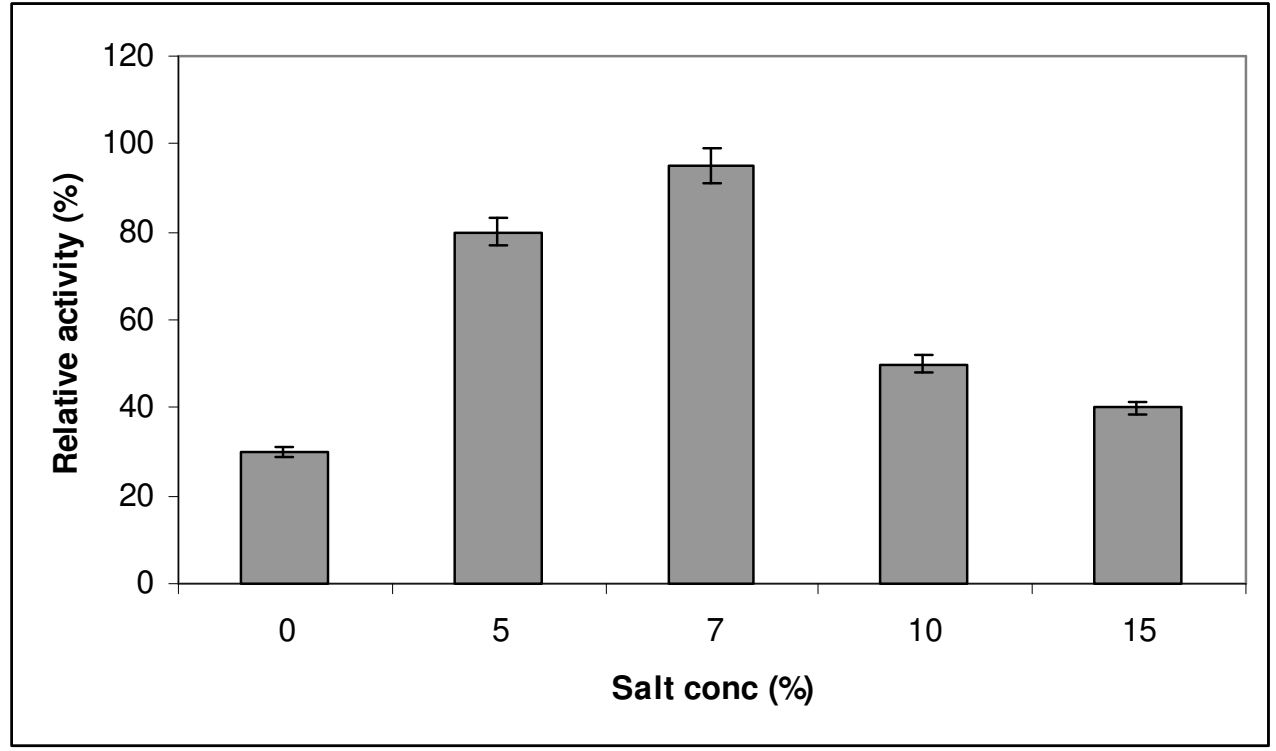

Figure 6. Effect of Salt Concentration on lipase production

\section{Purification of the enzyme}

The purification steps used in this study are lesser than the reports reported by various authors $(27,14)$. The Enzyme was purified and characterized. The reason for the application of shorter steps is of the fact that in each step of enzyme purification an average of more than $10 \%$ of the enzyme is lost and this led to the low recovery of the enzyme (Table 1). Hence to reduce the enzyme costs it is necessary to lower the number of the processing steps in order to increase the recovery. Further importance as in our study the enzyme could be recovered at lesser steps which simplified the tedium downstream processing for isolation of pure lipase and thus lower the cost of enzyme and hence influence the overall process of economy and thus of great industrial importance.

Table 1. Purification results

\begin{tabular}{|c|c|c|c|c|c|}
\hline Purification step & $\begin{array}{c}\text { Total } \\
\text { Protein }(\mathrm{mg})\end{array}$ & $\begin{array}{l}\text { Total Activity } \\
\text { (Units) }\end{array}$ & $\begin{array}{l}\text { Specific activity } \\
\text { (U/mg Protein) }\end{array}$ & Yield & Purification Fold \\
\hline Culture filtrate & 63 & 2394 & 38 & 100 & 1 \\
\hline $\begin{array}{l}\text { Ammonium sulphate } \\
\text { Precipitation }\end{array}$ & 13 & 1680 & 128 & 71 & 3.4 \\
\hline $\begin{array}{l}\text { Gel filtration on } \\
\text { Sephadex G-100 }\end{array}$ & 3 & 1170 & 398 & 48 & 10.3 \\
\hline
\end{tabular}

The molecular weight of the enzyme was estimated to be $33 \mathrm{kDa}$ by SDS-PAGE (Fig. 7). The pure protein smeared badly on native PAGE but showed single band with molecular weight of $33 \mathrm{kDa}$ on SDS-PAGE. This indicated that the lipase might be forming high molecular weight aggregates with other lipophilic materials. Lipases are reported to be monomeric proteins having molecular weights in the range of $16 \mathrm{kDa}-90$
$\mathrm{kDa}(9,25,30,17)$. In the present study it was found to have molecular weight in the aforesaid range therefore it might be a monomeric protein. Sodium dodecyl sulphate poly acryl amide gel electrophoresis analysis revealed the lipase protein to be monomer with a single distinct band. The molecular weight of the protein was determined to be $33 \mathrm{KDa}$. 


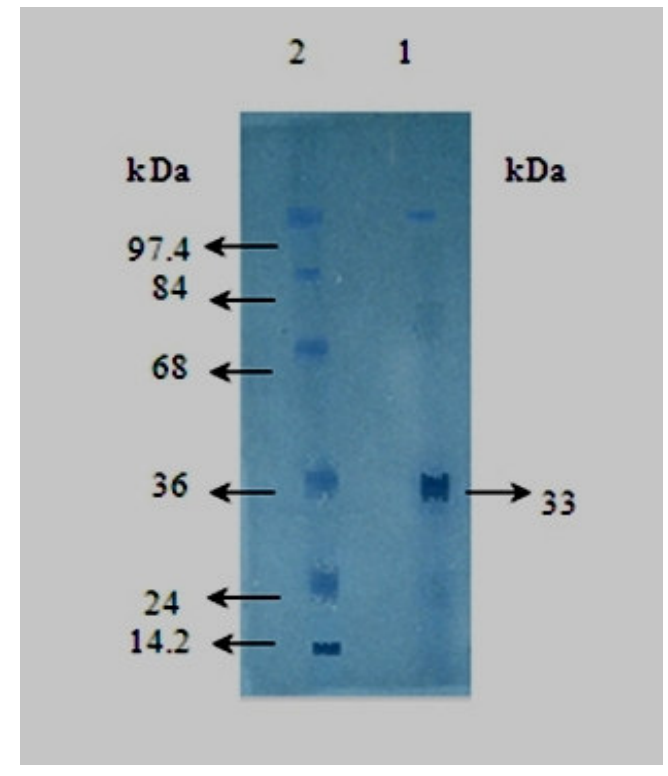

Figure 7. Gel showing the purified lipase. Lane 1. Lipase protein (investigated) Lane 2 Standard protein markers phosphorylase b (97.4 KDa), Fructose 6 phosphate kinase (84KDa), bovine serum albumin (68KDa), Glyceraldehyde 3 phosphate dehydogenase (36KDa), Trypsinogen (24 KDa), $\beta$ Lactoalbumin (14.2KDa).

\section{Effect of pH on the enzyme activity and stability}

The effect of $\mathrm{pH}$ on enzyme activity was studied in the $\mathrm{pH}$ range of $3.0-10$ at $50^{\circ} \mathrm{C}$ for 1 Hour. In the present work the optimum $\mathrm{pH}$ of the alkaline lipase was found to be 10.0. The enzyme was found to be stable in the $\mathrm{pH}$ range of 8-11 (Fig. 8). The lipase activity showed marked activation at alkaline $\mathrm{pH}$ of 8-10 with the retention of $90 \%$ of the residual activity at $\mathrm{pH} 11$. Based on the present findings the enzyme was stated to be alkaline lipase. The stability of the lipase at higher $\mathrm{pH}$, could be explained that the enzyme in the present study may contains more acidic amino acid that are exposed to or excreted to the external medium and a $\mathrm{Na}^{+}$cycle that facilitates the solute uptake. The $\mathrm{pH}$ optima in the present finding are relatively higher in comparison to the results reported earlier. In Bacillus thermoleovorans ID 1 (22), pH 6.5 in Staphylococcus aureus (25), pH 8.0 in Bacillus sp RSJ1 (33), pH 7.0 in Fusarium oxyporum (28), with an optimum $\mathrm{pH}$ in most of the Bacillus $\mathrm{sp}$ in the range of 5-8 (11).

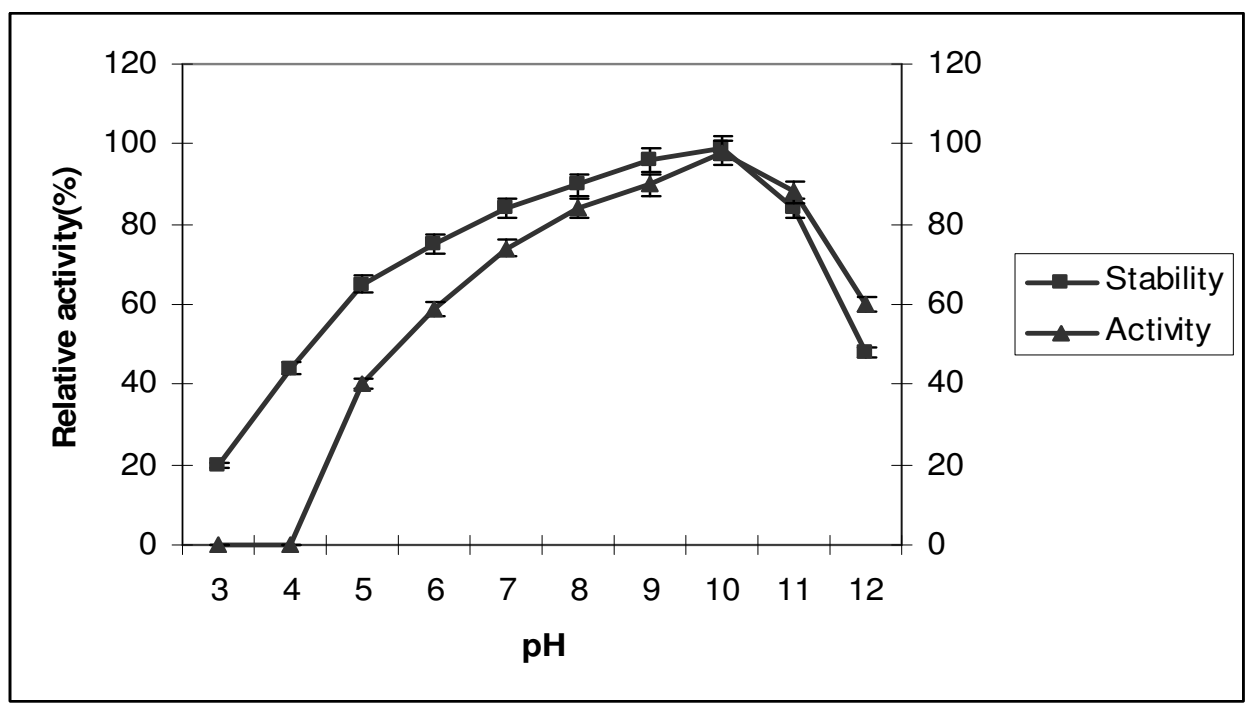

Figure 8. Effect of $\mathrm{pH}$ on activity and stability. 


\section{Effect of temperature on lipase activity and stability}

Lipase activity was assayed at different temperatures ranging from $10-80^{\circ} \mathrm{C}$ at $\mathrm{pH} 10$. The optimum reaction temperature was $60^{\circ} \mathrm{C}$. Thermal stability was investigated by incubating the enzyme at various temperatures $\left(30-80^{\circ} \mathrm{C}\right)$ for 1h. Thermo stability profile indicated that the enzyme showed great stability up to $60^{\circ} \mathrm{C}$ (Fig. 9). The lipase seems to keep $90 \%$ of activity at $60^{\circ} \mathrm{C}$ and almost $70 \%$ of the activity retained at $70^{\circ} \mathrm{C}$. The enzyme showed better stability than those reported by earlier authors $(16,19)$. The thermal stability of the lipase and retention of activity over $60^{\circ} \mathrm{C}$ could be explained by the presence of polyamines in the protein structure. However increased number of hydrogen bonds, salt bridges and higher proportion of thermophilic amino acids may also contribute towards the thermal stability of the enzyme at higher temperature. The results obtained are in agreement with lipase from Pseudomonas sp KWI-56 which was found to be stable at $60{ }^{\circ} \mathrm{C}$ but at a lower $\mathrm{pH}$ of 7.0 (6). Presently it is important to develop enzymes active and stable in broad range of temperatures, essentially due to the energy costs involved in the heating of the water, and the use of new and fragile materials. Higher temperatures are often used to remove difficult strains, such as food stains in cotton or synthetic materials.

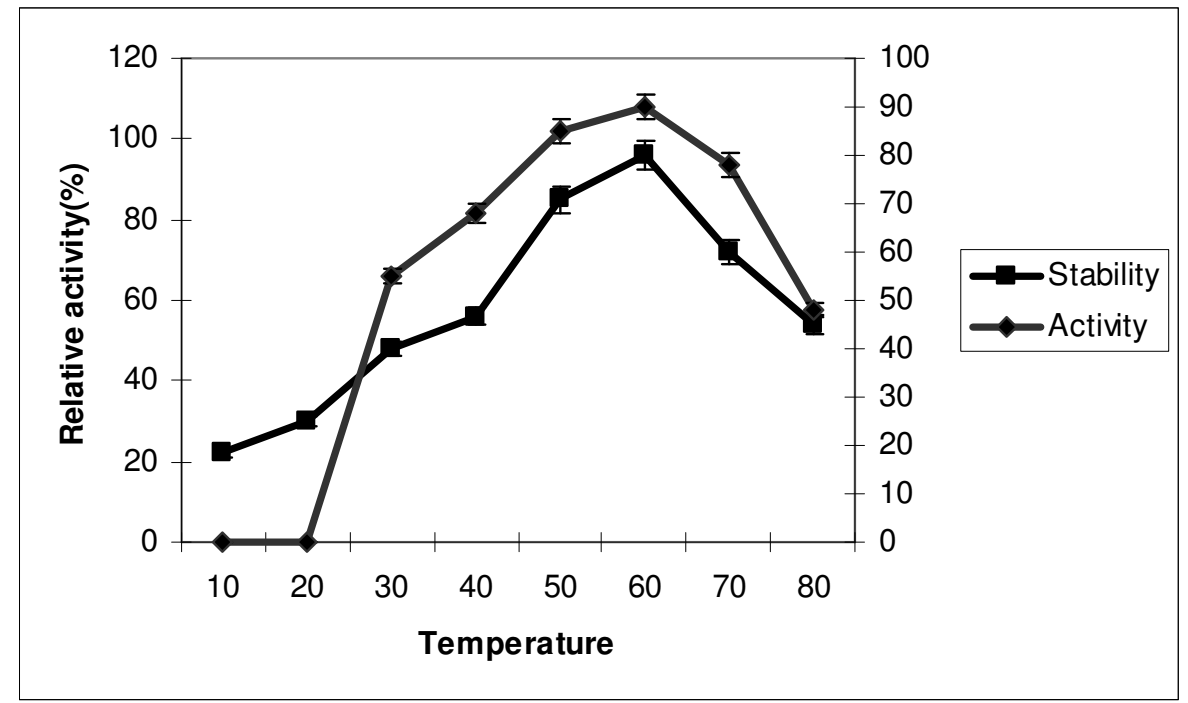

Figure 9. Effect of temperature on activity and stability

\section{Effect of Surfactants and detergents on lipase activity}

The effects of various surfactants and commercial detergents on the alkaline lipase activity were tested at $10 \%$ and $0.1 \%(\mathrm{w} / \mathrm{v})$ (Table 2) shows that the enzyme is stable in both ionic and nonionic surfactants. Tween 40 and Tween 80 were found to inhibit the lipase activity after $1 \mathrm{~h}$ of incubation at $50^{\circ} \mathrm{C}$. On the other hand, Triton X-100 and Triton X-114. It is interesting to note that Triton $\mathrm{x}-100$ and Triton $\mathrm{x}-114$ stimulated the enzyme activity up to $60 \%$ in our study. The reason may be that surface active agents might have increased the turnover number of lipase by increasing the contact frequency between the active site of the enzyme and the substrate by lowering the surface tension of the aqueous medium and with the maintenance of open form of lipase which may enhance the activity. SDS was found to be strong inhibitor as in the case of Bacillus thermoleovorans (7) lipases causing almost total inhibition of enzyme activity. The cause of strong inhibition by SDS could be due to the local conformation changes in the active site of the enzyme molecule that results in inhibition, partial reversible unfolding, and subsequent inactivation. 
Table 2. Effect of Surfactant and detergent on lipase activity

\begin{tabular}{ccc}
\hline Surfactants/Detergents & $(\boldsymbol{\%} \mathbf{w} / \mathbf{v})$ & Relative activity $(\%)$ \\
\hline Control & 100.00 & 100.00 \\
Surfactants & 10 & 99.05 \\
Tween 20 & 10 & 90.45 \\
Tween 40 & 10 & 100.34 \\
Tween 80 & 10 & 140.24 \\
Triton X-100 & 10 & 110.75 \\
Triton X-114 & 0.2 & 2.05 \\
SDS & 1 & 92.25 \\
Sodium Cholate & & \\
Commercial detergents & 1 & 50.00 \\
Surf & 1 & 44.24 \\
Ariel & 1 & 73.00 \\
Rin & 1 & 64.00 \\
Wheel & 1 & 80.00 \\
Tide & 1 & 72.09 \\
Fena & &
\end{tabular}

\section{Substrate specificity of enzyme}

Microbial lipases have been divided into three categories namely non specific, regiospecific and fatty acid specific based on the substrate specificity. The present lipase caused rapid hydrolysis of the vegetable oils containing C-16 and C18 fatty acid ester suggesting that the present lipase is a "true" lipase. It acted preferentially on oils with lower chain fatty acid. It showed marked activation with tributyrin as compared to triolein (20)
(Table 3). The activity of lipase in palm oil was considred to be $100 \%$ activity. Triacetin was found to be poor substrate and was hardly hydrolyzed. On the basis of present results the lipolytic activity is found to be dependent upon the unsaturated fatty acids as lipolytic activity increased with increase in the degree of unsaturation. Lipases from Bacillus thermocatenulatus, Staphylococcus hyicus and Staphylococcus epidermidis found to have hydrolysed tributyrin (31).

Table 3. Substrate specificity of the lipase

\begin{tabular}{cc}
\hline Substrate & Relative activity (\%) \\
\hline Castor oil (Ricinoleic acid Cn 18 with 85\%) & $35.7 \pm 0.02$ \\
Coconut oil (Lauric Acid, Cn 12 with 47.5\%) & $38 \pm 0.03$ \\
Cottonseed oil (Oleic acid Cn 18 with 50\%) & $42 \pm 0.01$ \\
Groundnut oil (Oleic acid Cn 18 with 56.6\%) & $64 \pm 0.03$ \\
Olive oil (Oleic acid Cn 18 with 50\%) & $53 \pm 0.02$ \\
Sunflower oil (Linolenic Acid Cn 18 with 48-74\%) & $48 \pm 0.04$ \\
Span 20 & $23 \pm 0.03$ \\
Triacetin & $0 \pm 0.02$ \\
Tributyrin & $50 \pm 0.03$ \\
\hline
\end{tabular}

\section{Effect of organic solvents on lipase activity}

Acetone was found to be best solvent for the extraction of lipase which showed an increase in lipase activity over the control. However the activity of the purified lipase was decreased by the addition of $40 \%$ of organic solvents including methanol, and isopropyl alcohol (Table 4). In contrast to the present study acetone was found to be the best solvent for the lipase. The present lipase is found to be stable in organic 
solvents with enhanced activity in the presence of acetone. The present findings were in agreement to that reported for Bacillus thermocatenulatus (31) and Pseudomonas sp. (17) where acetone has found to enhance enzyme activity. The observed stability of lipase is suggestive of the notion that the solvent maintains the enzyme in open conformation; the lid of the enzyme does not cover the active site crevice, and thus maintains the flexible conformation. The organic solvents were used in the concentration of $30 \%$ and not $1 \%$.

Table 4: Effect of organic solvents on lipase activity

\begin{tabular}{ccc}
\hline Solvents & Concentration $(\% \mathbf{~ v / v})$ & Relative activity \\
\hline Control & 0 & $100 \pm 0.03$ \\
Acetone & 30 & $120 \pm 0.01$ \\
Methanol & 30 & $60 \pm 0.03$ \\
Ethanol & 30 & $102 \pm 0.04$ \\
Iso propyl alcohol & 30 & $64 \pm 0.03$ \\
Butanol & 30 & $44 \pm 0.02$ \\
Propanol & 30 & $74 \pm 0.03$ \\
\hline
\end{tabular}

\section{CONCLUSION}

It is evident from the above study that the lipase has the requisite properties of significant industrial importance. A lipase that is stable at high alkaline conditions and high temperature is rare. In the present study Bacillus sp. LBN2, which produces inducible, extracellular, alkalophilic lipase stable in commercial detergents and surfactants, makes it ideally suited for detergent formulations. However, further investigation is required to ascertain the molecular characteristics, kinetic properties and substrate specificity to access the true potential of this microbial lipase.

\section{REFERENCES}

1. Abdel-Fattah, Y.R. (2002). Optimization of thermostable lipase production from a thermophilic Geobacillus sp. using Box-Behnken experimental design. Biotechnol Lett 24:1217-1222.

2. Ateslier, Z.B.B.; Metin, K. (2006). Production and partial characterization of novel thermostable esterase from a thermophilc Bacillus sp. Enzyme Microb Technol 38:628-635.

3. Baral, A.; Fox, P.F. (1997). Isolation and characterization of an extracellular lipase from Pseudomonas tolaassi. Fd.. Chem. 58: 33-38.

4. Bayoumi, R.A.; El-louboudey, S.S.; Sidkey, N.M.; Abd-El-Rahman,
M.A. (2007). Production, Purification and Characterization of Thermoalkalophilic Lipase for Application in Bio-detergent Industry. $J$. Apll. Sci. Res. 3: 1752-1765.

5. Boekema, K.H.A.; Beselin, M.; Breuer, B.; Hauer, M.; Koster, F.; Rosenau, K.; Tommassen, J. (2007). Hexadecane and Tween 80 stimulate lipase production in Burkholderis glume by different mechanisms. Appl. Environ. Microbiol., 73: 3838-3844.

6. Brune, A.K.; Gotz, F. (1992). Degradation of lipids by bacterial lipases. In Winkelmen G(ed) Microbial degradation of natural products, $\mathrm{VCH}$, Weinhein, pp 243-266.

7. Castro-Ochoa, L.D.K.; Rodriguez-Gomez, G.; Valerio-Alfaro, R.; OliartRos (2005). Screening, purification, and characterization of the thermoalkalophilic lipase produced by Bacillus thermoleovorans CCR11. Enzyme and Microbial Technology, 37: 648-654.

8. Ghanem, E.H.; Al-Sayed, H.A.; Saleh, K.M. (2000). An alkalophilic thermostable lipase produced by new isolate of Bacillus alcalophilus. World. J. Microbiol. Biotechnol. 16: 459-464.

9. Gilbert, E.J.; Cornish, A.; Jones, C.W. (1991b). Purification and properties of extrcellular lipase from Pseudomonas aeruginosa EF2. J. Gen. Microbiol. 137: 2223-2229.

10. Gulati, R.; Isar, J.; Kumar, V.; Prasad, A.K.; Parmar, V.S.; Saxena, R.K. (2005). Production of novel alkaline lipase from Fusarium globosum using neem oil. and its applications. Pure Appl Chem 77: 251-262.

11. Gupta, R.; Gupta, N.; Rathi, P. (2004). Bacterial lipases: an overview of production, Purification and Biochemical properties. Appl Microbiol Biotechnol 64: 763-781.

12. Kanwar, L.; Gogoi, B.K.; Goswami, P. (2002). Production of Pseudomonas lipase in n- Alkane substrate and its isolation using 
ammonium sulphate precipitation technique. Bioresource Technol. 84: 207-211.

13. Kader, R.; Yousuf, A.; Hoq, M.M. (2007). Optimization of lipase production by Rhizopus MR12 in shake culture. J Appl Sci 7: 855-860.

14. Kambourova, M.; Kirilova, N.; Mandeva, R.; Derekova, A. (2003). Properties of thermostable lipase from a thermophilic Bacillus steathermophilus MC7. J Mol Cat B. Enzymatic 22: 307-313.

15. Kaushik, R.; Saran, S.; Isar, J.; Saxena, R.K. (2006). Statistical optimization of medium components and growth conditions by response surface methodology to enhance lipase production byAspergillus carneus. J Mol Catal B: Enzym 40:121-126.

16. Kim, M.H.; Kim, H.K.; Lee, J.K.; Park, S.Y.; Oh, T.K. ( 2000). Thermostable lipase from Bacillus steathermophilus: high level production, purification, and calcium dependent thermostability. Biosci Biotechnol Biochem 64: 280-286.

17. Kiran, S.G.; Shanmughapriya, S.; Jayalakshmi, J.; Selvin, J.; Gandhimathi, R.; Sivaramakrishnan, S.; Arunkumar, M.; Thangavelu, T.; Natrajaseenivasan, K. (2008). Optimization of extracellular psychrophilic lipase produced by marine Pseudomonas sp. (MSIO57). Bioprocess Biosyst Eng 31: 483-492.

18. Konstantinou, P.; Roussis I..G. (1998). Some properties of extracellular lipase from Pseudomonas 92. Mlichwissenschaft 53:622-624.

19. Kulkarni, N.; Gadre, R.V. (2002). Production and properties of an alkaline thermophilic lipase from Pseudomonas flourescens NS2W. J Ind Food Microbiol 28: 344-348.

20. Kumura, H.; Mikawa, K.; Saito, Z. (1993) Purification and characterization of lipase from Pseudomonas fluorescens No. 33. Milchwissenschaft 48: 431-434.

21. Lanser, A.C.; Manthey, L.K.; Hou, C.T. (2002). Regioselectivity of new bacterial lipases detemined by hydrolysis of triolein. Curr Microbiol 44: 336-340.

22. Lee, D.W.; Koh, Y.S.; Kim, K.J.; Kim, B.C.; Choi, H.J.; Kim, D.S.; Suhartono, M.T.; Pyun, Y.R. (1999). Isolation and characterization of thermophilic lipase from Bacuillus thermoleovorans ID-1. FEMS Microbiol Lett 179: 393-400.

23. Lotti, M.; Monticelli, S.; Montesinos, J.L.; Brocca, S.; Valero, F.; Lafuente, J. (1998). Physiological control on the expression and secretion of Candida rugosa lipase. Chem Phys Lipids. 93: 143-148.

24. Lowry, O.H.N.G.; Rosebrough, A.L.; Farr Randall, R.J. (1951). Protein measurement with the Folin- phenol reagent. J. Bio. Chem. 193: 265-
275.

25. Paiva, A.L.; Balaco, V.M.; Malacta, F.X. (2000). Review: Kinetics and mechanisms of reaction catalaysed by immobilized lipases. Enz Microbiol Technol 27: 187- 204.

26. Paetzel, M.; Karla, A.; Strynadka, N.C.J.; Dalbey, R.E. (2002). Signal Peptidases. Chem Rev 2002, 102:4549-4579.

27. Palekar, A.A.; Vasudevan, P.T.; Yan, S. (2000). Purification of lipase: A review. Biocatal Biotransform 18: 177-200.

28. Prazeres, J.N.; Cruz, J.A.B.; Pastore, G.M. (2006). Characterization of an alkaline lipase from Fusarium oxysporum and the effect of different surfactants and detergents on the enzyme activity. Braz J Microbiol 37: 505-509.

29. Rahman, R.N.Z.A.; Lee, P.G.; Basri, M.; Salleh, A.B. (2005). Physical factors affecting the production of organic solvent-tolerant protease by Pseudomonas aeruginosa strain K. Bioresource Technol 96:429-436.

30. Rathi, P.; Saxena, R.K.; Gupta, R. (2001). A novel alkaline lipase from Burkholderia cepacia for detergent formulation. Process Biochem 37: 187-192.

31. Schmidt-Dannert, C. (1999). Recombinant microbial lipases for biotechnological application. Bioorg Med Chem 7: 2123-2130.

32. Schuepp, C.; Kermasha, S.; Michalski, M.C.; Morin, A. (1997). Production, partial purification and characterization of lipases from Pseudomonas fragi CRDA 037. Process Biochem 32: 225-232.

33. Sharma, R.; Chisti, Y.; Banerjee, U.C. (2001). Production, Purification, Characterization and applications of lipases. Biotechnol. Advances 19: 627-662.

34. Sharma, R.; Soni, S.K.; Vohra, R.M.; Gupta, L.K.; Gupta, J.K. (2002). Purification and characterization of a thermostable alkaline lipase from a new thermophilic Bacillus sp RSJ -1. Process Biochem 37: 1075-1084.

35. Sigurstdair, S.; Konraosdottir, M.; Jonsson, A.; Kristjansson, J.K.; Mathiasson, E.; (1993).Lipase activity of thermophilic bacteria from Icelendic hotsprings. Biotechnol Lett 15: 361-366.

36. Sugihara, A.; Tadaki, T.; Yosio, T. (1991). Purification and characterization of a novel thermostable lipase from Bacillus sp. J. Biochem. 109: 211-216.

37. Taipa, M.A.; Aires-Barros, M.R.; Cabral, J.M.S. (1992). Production of lipases. J. Biotechnol 26: 111-142.

38. Thomas, A.; Manoj, M.K.; Valsa, A.; Mohan, S.; Manjula, R. (2003). Optimization of growth condition for the production of extra cellular lipase by Bacillus mycoides, Indian J. Microbiol. 43: 67-69. 